\title{
TRADISI MEMASUKI RUMAH BARU PADA SUKU JAWA DI KOTA MEDAN
}

\author{
Siti Nur Khodijah ${ }^{1}$ \\ Mahasiswa Prodi PBSID FKIP UMN Al Washliyah ${ }^{1}$ \\ sitinurkhodijah848@gmail.com \\ Rosmawati Harahap ${ }^{2}$ \\ Dosen Prodi PBSID FKIP UMN Al Washliyah ${ }^{2}$ \\ dahlanrahmawati59@gmail.com
}

\begin{abstract}
Abstrak
Masalah penelitian ini adalah apakah masyarakat Jawadi Kota Medan masih melakukan acara tradisi memasuki rumah baru? Tujuan penelitia peneliti inginmendeskripsikan beberapa orang bersuku Jawa di Kota Medan masih melakukan acara tradisi memasuki rumah baru. Metode penelitian ini adalah metode kualitatif deskriptif. Sumber datanya adalah teks informasi tentang perilaku acara tradisi memasuki rumah baru di daerah Jalan Panglima Denai dan Kecamatan Medan Tembung. Instrumen penelitiannya adalah observasi dan wawancara. Data utama penelitian ini didapatkan melalui wawancara mendalam yang dilakukan peneliti pada kurun waktu bulan Juli sehingga bukan September 2018. Peneliti wawancarai beberapa orang pemilik rumah baru yang bersuku Jawa di Kota Medan. Lokasi penelitian ini yaitu Medan Denai, dan Medan Tembung. Pelaku acara tradisi memasuki rumah baru bersuku Jawa di Jalan Panglima Denai dan Medan Tembung telah terjadi perlakuan tradisi memasuki rumah baru yang disertai ritual berdoa yang sesuai ajaran Islam yaitu doa keselamat, minta rezeki, bahagia, nyaman, aman, dan tenteram, empati bagi orang lain kelak di hari nanti .Biasanya masyarakat suku Jawa dari rumah lamanya akan berbondong-bondong mengantarkan orang tersebut dalam melakukan pindah rumah barunya. Adat ini pun masih berlangsung sampai sekarang digunakan pada masyarakat suku Jawa. Sebagian masyarakat pada suku Jawa masih ada yang percaya mengenai adat istiadat memasuki rumah baru mengenai bacaan-bacaan dan ada ebagian masyarakat yang hanya ikut-ikutan saja dan tidak tahu pada maksud dari makna tradisi memasuki rumah baru itu.
\end{abstract}

Kata kunci: rumah baru, suku jawa, tradisi, ritual, doa.

\begin{abstract}
The problem of this research is whether the Jawadi people of Medan City still perform traditional events entering a new house? The aim of the study is that researchers want to describe some Javanese people in the city of Medan who are still carrying out traditional events entering new homes. This research method is descriptive qualitative method. The data source is a text of information about the behavior of traditional events entering a new home in the area of Jalan Panglima Denai and Kecamatan Medan Tembung. The research instruments were observation and interview. The main data of this study were obtained through in-depth interviews conducted by researchers in the period of July so that it was not September 2018. Researchers interviewed several new homeowners who were Javanese in Medan. The location of this research is Medan Denai, and Medan Tembung. The perpetrators of the tradition of entering a new Javanese house on Jalan Panglima Denai and Medan Tembung has been treated to the tradition of entering a new house accompanied by rituals of prayer that are in accordance with the teachings of Islam, namely salvation, asking for sustenance, happiness, comfort, security, and peace. Usually Javanese tribesmen from their old houses will flock to the person to move their new house. This custom is still in use today in Javanese tribes. Some people in Javanese tribes still believe in customs entering a new house about reading and there are some people who just follow along and do not know the meaning of the tradition of entering the new house.
\end{abstract}

Keywords: new house, Javanese tribe, tradition, ritual, prayer. 


\section{PENDAHULUAN}

\subsection{Latar Belakang Masalah}

Masyarakat yang bersuku Jawa di Kota Medan banyak yang berasal dari Jawa. Tetapi ada juga merekayang kelahiran Kota Medan. Mereka suka merekrut budaya Jawa kareana keseringan tampak ber tradisi yang bernuansa budaya Jawa. Karena tidak percaya dengan hal-hal seperti itu ada yang percaya dan juga tidak percaya. Tetapi masih banyak. kontribusinya setidaknya dengan menginventaris tradisi yang masih dilakukan oleh masyarakat supaya nilai-nilai luhur Jawa yang terkandung dalam tradisi makna tradisi memasuki rumah baru di Kota Medan pada suku Jawa, sebagai salah satu bentuk kebudayaan agar tidak hilang seiring berjalannya waktu serta supaya masyarakat dapat mengetahui identitas dan jati dirinya sebagai warga Negara Indonesia yang berkebudayaan, apalagi dengan semakin modernnya zaman serta pengaruh asing yang masuk ke Indonesia. Dalam rangka keperluan pengembangan budaya peneliti ingin metngetahui tradisi budaya Jawa yang pernah dilakukan merekamasa sekarang. Rumusan masalah penelitian ini adalah apakah masyarakat Jawadi Kota Medan masih melakukan acara tradisi memasuki rumah baru?

\subsection{Tujuan Penelitian}

Peneliti ingin mendeskripsikan beberapa orang bersuku Jawa di Kota Medan yang masih melakukan acara tradisi memasuki rumah baru.

\section{METODE}

Metode penelitian ini adalah metode kualitatif deskriptif (Sugiyono, 2011 dan Endaswara, 2006). Sumber datanya adalah teks informasi tentang perialku acara tradisi memasuki rumah di daerah Jalan Panglima Denai dan Pasar 7 Kecamatan Medan Tembung. Instrumen penelitiannya adalah observasi dan wawancara.

\subsection{Informan Penelitian}

Adapun nama-nama dari narasumber dalam penelitian adalah sebagai berikut:

Data informan yang diwawancarai terdapat dalam bagan berikut.

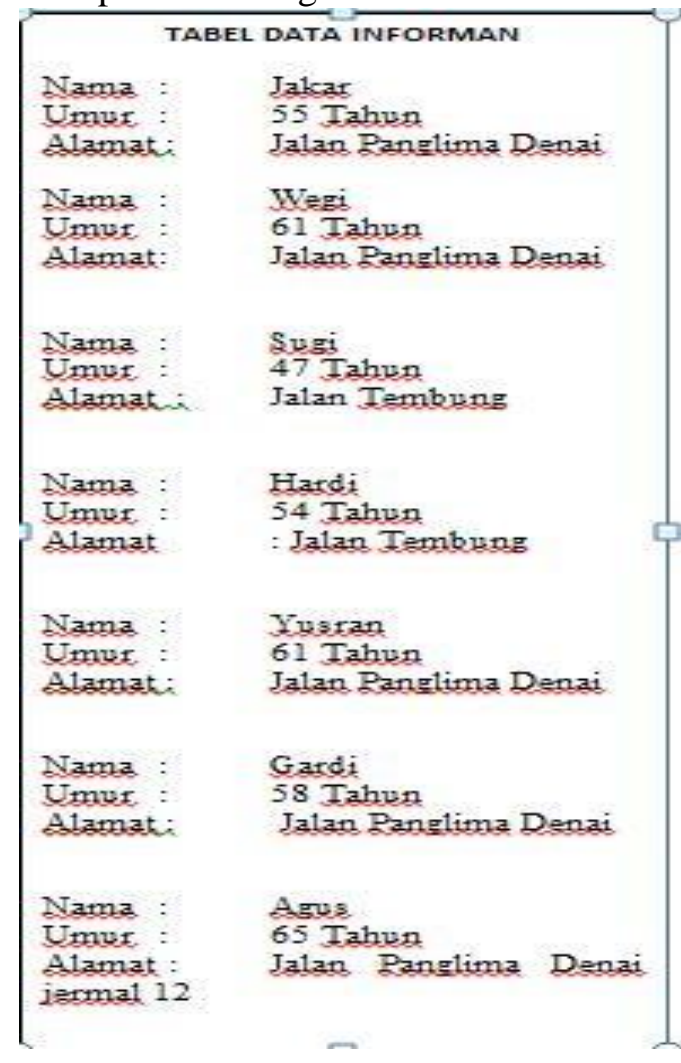

Berdasarkan Kartu Tanda Penduduknya (KTP) bahwa mereka adalah semua orang yang berkelahiran di luar pulau Jawa. Dengan kata lain informan ini sekarang berdomisi dan membangun rumah tempat tinggalnya di Jalan Penglima Denai dan dan Pasr 7 Tembung Medan. Mereka bersuku Jawa dan mereka berkomunikasi dengan tetangga dengan bahasa Indonesia ragam informal.

\section{HASIL DAN PEMBAHASAN}

Pembahasan yang relevan untuk menjelaskan data tentang acara tradisi memasuki rumah adalh bubu metodologi 
yang menentukan data dan teknik analisisnya bersesuaian dengan kajian teks. Data tradisi termasuk teks. Referensi yang dirujuk dalam penelitian ini berujukan buku-buku karangan Endaswara (2008) teori dan penerapan penelitian sastra. bahwa data penelitian kebudayaan yang berepistimologi kebudayaan. Makanya Kamus Besar Bahasa Indonesia pun bisa digunakan untuk menjelaskan makana bahasa Jawa yang tertulis cetak miring yang ikut cara Tim Penulis Kamus Besar Bahasa Indonesia (2008).

Makna tanda hari baik yang dipercayai untuk melaksanakan acara memasuki rumah baru menggunakan rujukan buku karangan Endraswara (2003). Dalam buku ini dijelaskan pranata dan sarana mendirikan rumah yang sesuai falsafah hidup Jawa.

\subsection{Hasil Penelitian}

Berdasarkan hasil observasi dan wawancara maka peneliti mendapat sejumlah data yang berkaitan dengan judul penelitian: Makna Tradisi Memasuki Rumah Baru di Kota Medan Pada Suku Jawa. Masyarakat suku Jawa di Kecamatan Medan Denai dan Medan Tembung masih ada yang melakukan acara tradisi memasuki rumah baru. Berdasarkan hasil wawancara bahwa 4 rumah baru di Kecamatan Medan Denai melakukan acara tradisi memasuki rumah baru. Masyarakat suku Jawa di Medan Tembung ada 3 rumah baru dimasuki dengan acara yang sesuai dengan bacaan upacara saat memasuki rumah baru pada suku Jawa di Kota Medan. Bacaan yang sesuai referensi yang di dalam daftar pustaka; langkah-langkahnya sebagai berikut.

1) Assalamualaikum ngajaga omah iki nganti pirang-pirang taun saiki ana ngajaga omah sing anyar iki nggawe ngajaga omah urip sing tentram lan nmyaman manggoni omah anyar.
Artinya: Assalamualikum wahai penjaga rumah ini selama bertahuntahun sekarang ada penjaga rumah ini yang baru buatlah penjaga rumah ini hidupnya tentram dan nyaman menempati rumah baru ini.

2) Gawe ngajaga omah anyar iki adoh saka penyakit.

Artinya: Buatlah penjaga rumah yang baru ini dijauhkan dari penyakit.

3) Ngagawe omah sing ngenggoni omah anyar iki iso terus menehi rezeki lan ora tau ngeculake.

Artinya: Buatlah yang menempati rumah baru ini mendapat rezeki terus dan tak pernah putus.

4) Supaya Master omah tansah ing pikiran cahya lan rezeki kantli gampang.

Artinya: Agar si empu rumah selalu dalam pikiran terang dan mendapat rezeki dengan mudah.

Informan yang memasuki rumah baru di Jalan Panglima Denai Kecamatan Medan Denai melakukan acara tradisi memasuki rumah yang masih menggunakan tradisi tersenut karena sudah turun-temurun dilakukan oleh nenek moyangnya tetapi acara doanya dilaksanakan sesuai teks doa agama Islam. Sebagian orang menggunakan tradisi tersebut tetapi tidak tahu maksud makna tradisi tersebut.

Apalagi zaman sudah makin modern banyak yang tidak percaya dengan hal - hal seperti itu, ada sebagian orang itu musyrik. Tidak semua tradisi atau adat-istiadat di lakukan masyarakat Jawa sama, walaupun tidak sama tradisi yang dilakukan masyarakat suku Jawa tetapi maksud makna nya tetap sama juga.

Makna tradisi memasuki rumah baru pada suku Jawa yaitu agar si pemilik rumah atau yang menempati rumah baru tersebut diberi kesehatan dijauhkan dari penyakit, kemudahan rezekinya, tentram, aman, dan nyaman. 


\subsection{Pembahasan}

Hasil penelitian ini didapatkan datanya melalui wawancara mendalam yang dilakukan peneliti pada kurun waktu bulan Juli 2018. Peneliti melakukan penelitian melalui wawancara kepada masyarakat yang ada di Kota Medan (Medan Denai, Medan Tembung). Demikianlah dilakukan penelitian pada masyarakat yang ada berada di daerah Medan Denai.

Masyarakat suku Jawa biasanya setiap hendak memasuki rumah baru melaksanakan ritual untuk mengirinya dalam menempati rumah baru nanti. Dan biasanya masyarakat (warga ) suku Jawa dari rumah lamanya akan berbondongbondong mengantarkan orang tersebut dalam melakukan pindah rumah barunya. Adat ini pun masih berlangsung sampai sekarang digunakan pada masyarakat suku Jawa.

"Sebagian masyarakat pada suku Jawa masih ada yang percaya mengenai adat istiadat memasuki rumah baru mengenai bacaanbacaan dan ada sebagian masyarakat yang hanya ikut-ikutan saja dan tidak tahu pada maksud dari makna tradisi memasuki rumah baru".

Bukan dengan bacaan-bacaan saja tetapi masyarakat jawa juga menggunakan hari baik untuk memasuki rumah baru, tidak sedikit masyarakat jawa yang masih memegang teguh adat dan kepercayaan tradisional harus mendatangi seseorang yang dianggap tau cara menentukan hari baik pindah rumah, hanya untuk menanyakan/mencari hari baik pindah rumah. Hal ini dilakukan sebagai wujud ikhtiar (berhati-hati kepada Sang Maha Memiliki, mereka sadar bahwa mereka hanya menumpang tanah milik sang Maha Pencipta, dengan kata lain mereka tidak sembrono menempati tempat yang hanya titipan sang Maha Pemilik. Tentunya dengan harapan nantinya tempat tersebut membawa hal-hal baik bagi penghuninya.

Di tengah masyarakat pada suku mengenai "Makna Tradisi Memasuki Rumah Baru Di Kota Medan Pada Suku Jawa". Masyarakat pada suku Jawa memiliki kebiasaan membuat selamatan ketika memasuki rumah baru. Berbagai ritualpun dilakukan baik dengan pembacaan surat tertentu secara jama'i, tahlilan, doa-doa, atau bahkan berbau syirik pun ada yang dilakukan. Dan masih ada masyarakat yang tidak percaya akan hal seperti itu, tetapi pada masyarakat zaman dahulu masih mempercayai mengenai hal seperti itu.

Tidak semua orang memahami apa makna yang terkandung dari suatu ritual-ritual yang dilakukan, sebagian orang jawa hanya melakukan dan melaksanakan syarat-syarat, ritual-ritual, atau bacaan-bacaan doa tanpa memahami secara mendalam maknanya, karena dipercayai hanya sebagai syarat untuk mendapatkan keselamatan dan keridhoan dari Tuhan Yang Maha Esa. Terdapat berbagai cara dan keyakinan turuntemurun yang harus dilakukan menurut adat istiadat pada suku Jawa.

"Menurut Bapak Jakar berusia 55 tahun warga daerah kota Medan Denai Bapak Jakar sebagai orang Jawa mengetahui tentang Memasuki Rumah Baru menentukan hari yang baik untuk pindah rumah (Memasuki Rumah Baru). Pada masyarakat suku Jawa untuk pindah rumah melakukan ritual-ritual dan bacaan doa, dan memberikan sesajen, disini diartikan bukan untuk makhluk mistis namun dijadikan persyaratan untuk memasuki rumah baru".

Masyarakat suku Jawa memiliki berbagai macam cara untuk memasuki rumah baru. Di dalam tradisi memasuki 
rumah baru tidak saja menggunakan bacaan-bacaan saja, tetapi juga menggunakan sesajen-sesajen juga bisa, tetapi untuk sekarang dengan berkembangnya zaman yang sudah modern banyak sekali masyarakat suku Jawa yang tidak tahu dari makna tradisi memasuki rumah baru. Ada juga masyarakat suku Jawa yang tidak percaya dengan hal-hal seperti itu dan seabgian masyarakat suku Jawa masih mempercayainya. Ada juga masyarakat suku Jawa yang menentukan hari baik untuk memasuki rumah baru.

\section{Bulan Baik untuk Memasuki Rumah Baru}

1. Bulan Sura 'tidak baik'

2. Bulan Sapar 'tidak baik'

3. Bulan Mulud 'tidak baik'

4. Bulan Bakdamulud 'baik'

5. Bulan Jumadilawah 'tidak baik'm

6. Bulan Jumadiakhir 'kurang baik'

7. Bulan Rajab 'tidak baik'

8. Bulan Ruwah 'baik'

9. Bulan Pasa 'tidak baik'

10. Bulan Sawal 'sangat tidak baik'

11. Bulan Dulkaidah 'cukup baik'

12. Besar 'sangat baik'

Berdasarkan perhitungan di atas, bulan yang baik adalah: Bakdamulud, Ruwah, Dulkaidah, dan Besar. Watak bulan baik pada memasuki rumah baru :

a. Bulan Bakdamulud: Bulan baik untuk mendirikan sesuatu termasuk rumah tinggal, keluarga yang bersagkutan mendapat wahyu keberuntungan, apa yang diinginkan terlaksana, cita-citanya tercapai, selalu menang dalam menghadapi perkara, berhasil dalam bercocok- tanam, berkelimphan emas dan uang, dan dilindungi dari Allah Swt.

b. Bualn Ruwah: bulan baik untuk mendirikan rumah tinggal, rejeki melimpah dan halal, disegani, dihormati dan disegani orang banyak.

c. Bulan Dulkaidah: cukup baik, dicintai anak istri, para orang tua, saudara dan handaitaulan. Dalam hal becocok-tanam lumayan hasilnya, banyak rezeki dan cukup uang, keadaan keluarga harmonis, tentram, dan damai.

d. Bulan Besar: baik, banyak mendapat rezeki, berkelimpahan harta-benda dan uang. Anggota keluarga yang berdiam di areal rumah tinggalnya yang dibangun pada bulan besar merasakan ketentraman lahir batin, serta dihormati.

Setelah menghitung penanggalan yang baik ( bulan baik memasuki rumah baru ) pada masyarakat Jawa juga melakukan ritual-ritual baca doa dan memberikan sesajen-sesajen. Syarat-syarat yang dilakukan memiliki makna agar kedepannya si pemakai rumah akan mendapat rezeki yang terus dan tak pernah putus.

Menurut Bapak Wegi, berumur 61 tahun, yang bertempat tinggal di Jalan Panglima Denai.

Bapak Wegi memang asli orang Jawa kedua orang Bapak Wegi memang keturunan orang Jawa. Menurut Bapak Wegi mengenai adat-istiadat suku Jawa saat memasuki rumah baru memang harus di lakukan karena sudah turun-temurun dari nenek moyang; Bapak Wegi sendiri pun masih melakukan adat-istiadat tersebut. Yang pak Wegi tahu mengenai adat-istiadat tentang Makna tradisi memasuki rumah baru, yang pak wegi tahu mengenai hari baik, karena di hari yang baik kalau kita mau memasuki rumah baru paling utama harus menetukan hari baik agar rumah baru yang kita tempati 
terasa nyaman dan di perlancarkan rezeki kita. Tetapi masih ada seseorang yang tidak percaya akan hal-hal seperti itu karna rezeki sudah Allah yang mengatur dan menetukannya. Begitu menurut pendapat dari Bapak Wegi”.

Menurut hasil wawancara di atas menurut menurut penelitian Bapak Wegi masih menjunjung tinggi tentang nilai tradisi. Tradisi yang dilakukan secara tutn - temurun, Bapak Wegi percaya tentang adanya tradisi tersebut makna tradisi yang dilakukan Bapak Wegi agar sih pemilik rumah baru atau yang menepati rumah baru dipermudahkan rezekinya, diberi kesehatan, tentram, aman, dan nyaman.

\subsubsection{Bacaan Doa Saat Memasuki Rumah Baru}

Ada juga masyarakat suku Jawa yang menggunakan bacaan doa saat memasuki rumah baru. Makna dari memasuki rumah baru pada suku Jawa yang berada di daerah Kota Medan yang di sekitar Medan Denai, dan Medan Tembung. Tidak semua masyarakat yang suku Jawa tahu tentang Makna dari tradisi memasuki rumah baru tersebut. Masih banyak masyarakat yang bersuku tidak tahu atau tidak memahami tentak makna tradisi tersebut,

Maksud dari makna tradisi memasuki rumah baru yaitu sebelum kita memasuki rumah yang akan kita tempati terlebih dahulu kita memberikan syaratsyarat agar kita nantik saat menepati rumah tersebut terasa tentram, nyaman dan di berikan kelancaran rezeki, seperti yang di ketahui masyarakat yang berada di daerah Medan Denai dan Medan Tembung, mereka memiliki perbedaan dalam tradisi adat-istiadat saat memasuki rumah baru.

\subsubsection{Bacaan Doa Saat Memasuki Rumah Baru pada Suku Jawa Menurut Ajaran Islam}

"Masyaallah Laaquwwatailla Billah" Maksud yaitu agar membuat hati kita menjadi tentram dan nyaman karena Allah akan senantiasa menjaga dan melindungi kita yang tinggal di atau menempati rumah batu.

Menurut Bapak Sugi berusia 47 tahun, bertempat di Jalan Tembung Pasar 3 Medan.

$\begin{array}{lcr}\text { Mengenai } & \text { makna } & \text { tradisi } \\ \text { memasuki } & \text { rumah } & \text { baru } \\ \text { menggunakan } & \text { bacaan } & \text { doa }\end{array}$ tersebut agar kita menempati rumah yang baru kita tempati agar kita merasa nyaman saat berada di rumah baru yang sedang kita tempati dan kita merasa ketentraman saat berada di rumah baru yang kita tempati dan di berikan ke berkahan ke Allah swt. Bapak Sugi berusia 47 tahun, bertempat di Jalan Tembung Pasar 3 Medan itu memasuki rumah baru ingin merasa nyaman jika rumah barunya ditempatinya.

\subsubsection{Bacaan Saat Memasuki Rumah Baru Pada Suku Jawa}

Assalamualaikum ngajaga omah iki nganti pirang-pirang taun saiki ana ngajaga omah sing anyar iki nggawe ngajaga omah urip sing tentram lan nyaman manggoni omah anyar.

(Sumber: Endraswara, 2003).

Doa itu sesuai dengan ajaran penganut falsafah dan agama Islam yang diucapka sewaktu ada acara mendirikan rumah. Menurut Bapak Hardi berusia 54 tahun, bertempat di jalan tembung pasar 7 makna dari tradisi memasuki rumah baru memiliki bacaan-bacaan tertentu, dan maksud dari bacaan atau doa saat memasuki rumah baru yaitu agar sih pemilik rumah hidupnya tentram dan nyaman.

\footnotetext{
" Gawe ngajaga omah anyar iki adoh saka panyakit".
} 
Menurut bapak Yusran berusia 61 tahun, bertempat tinggal di Jalan Panglima Denai makna dari tradisi memasuki rumah baru seperti yang di ketahui bapak Yusran makna tersebut agar sih pemilik rumah di jauhkan dari penyakit dan nyaman saat menempati rumah baru.

" Nggawe omah sing ngenggoni omah anyar iki iso terus menehi rezeki lan ora tau ngeculake" .

Menurut bapak Gandi, berusia 58 tahun yang bertempat tinggal di jalan Panglima Denai makna dari tradisi memasuki rumah baru tersebut yaitu tradisi memasuki rumah baru memang sudah turuntemurun dari nenek moyang kita, dan maksud makna tradisi memasuki rumah yaitu dengan bacaan doa dan kita sambil berjalan dan mesapu-sapukan rumah agar rezeki kita lancar terus.

" Supaya master omah tansah ing pikiran cahya lan rezeki kantli gampang.

Menurut bapak Agus, berusia 65 tahun yang di bertempat tinggal Di Jalan Panglima Denai Jermal 7 makna tradisi memasuki rumah baru yaitu yang saya ketahui tentang makna tradisi memasuki rumah baru yaitu kita memasuki rumah tersebut membaca bacaan dan kita kita masuk kedalam rumah membawa air putih di letakkan di belakang pintu agar kita menempati rumah baru tersebut selalu dalam pikiran tenag dan mendapatkan rezeki dengan mudah.

Berdasarkan hal di atas dapat diketahui bahwa makna tradisi memasuki rumah baru di Kota Medan pada suku Jawa, yaitu masyarakat yang suku Jawa mengetahui tentang adat-istiadat mengenai makna tradisi memasuki baru apalagi masyarakat yang sudah modern tidak percaya akan hal-hal seperti itu dan sebagian masyarakat mempercayainya sebab mereka mengikuti adat-istiadat dari turun temurun yang di lakukan oleh nenek moyang.

Makna-makna yang terdapat dalam tradisi makna tradisi memasuki rumah baru menunjukkan bahwa pandangan hidup masyarakat Jawa mengenai kehidupan sangatlah kompleks. Masyarakat Jawa sadar akan pentingnya melestarikan tradisi adat Jawa. Bagi masyarakat suku Jawa, keseimbangan dalam hubungan antara Tuhan, alam dan lingkungan sangatlah penting. Dengan masih dilaksanakannya tradisi makna tradisi memasuki rumah baru pada suku Jawa juga masih menempatkan pengharapan akan suatu hal yang lebih baik dalam perjalanan kehidupannya.

\section{KESIMPULAN}

Berdasarkan hasil penelitian dan data yang penulis kumpulkan dan amati dapat disimpulkan bahwa makna yang terkandung dalam tradisi memasuki rumah baru pada masyarakat suku Jawa di Kota Medan adalah:

1. Pemilik rumah baru yang menghuninya merasa nyaman, aman, tenteram, dan mudah rezekinya.

2. Pemilik rumah baru yang menghuninya berbadan sehat selalu.

3. Pemilik rumah baru yang menghuninya merasa pikiran tenang.

\section{DAFTAR PUSTAKA}

Endraswara, Suwardi. (2008). Metodologi Penelitian Sastra. :Media Pressindo.

Endraswara, Suwardi. (2003). Mendirikan Rumah, Falsafah Hidup Jawa, Yogyakarta: KDT. 
Sugiyono. (2011). Metode Penelitian Pendidikan Kualitatif, Bandung: Alfabeta.

Tim. Penulis (2008). Kamus Besar Bahasa Indonesia, Jakarta: Balai Pustaka. www.spengetahuan.com/2017/10/pengert ian-tradisi-tujuan-fungsi-macam-macamcontoh-penyebab-perubahan.html. di akses 18 Maret 2018.

https://www.kompasiana.com/layyinatus y.syifa/adab-ketika-menempati-rumahbaru-dalam-islam54f9115da333115f378b4aff. di akses 18 Maret 2018

Waridah.2017.pengetahuan.http://www.b imbelbahasaindonesia.com/2016/10/peng ertian-dan-contoh-maknakonotatif.html?m=1. di akses 18 Maret 2018

http://www.spengetahuan.com/2018/03/p engertian-semantik-menurut-para-ahliunsur-jenis-jenis.html. diakses 18 Maret 2018 